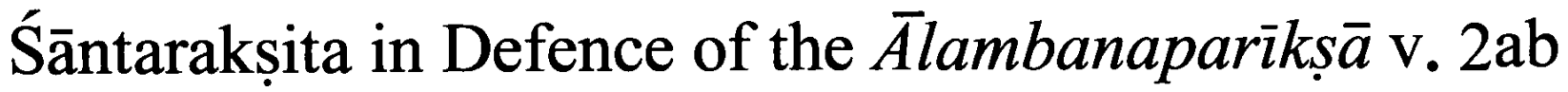

\section{MatsuoKa Hiroko}

0. In the Bahirarthaparīkșā (BP) of his Tattvasangraha (TS) vv. 4-15 ( TS $\left._{\mathrm{B}} 1967-78\right)$, Śāntarakșita attacks Śubhagupta's counter-argument (Bāhyārthasiddhikārikā [BASK] vv. $38-40$ ) to refute the claim made by Dignāga in the $\bar{A}$ lambanaparikșa ( $\overline{\mathrm{AP}}$ ) v. 2ab that an aggregate of atoms cannot serve as an objective basis for sensory cognition. MATILAL (1981) has explained TS BP 8-11 and MiKogamI (1983) has translated TS BP 1-33 TS $_{\mathbf{B}}$ 1964-93) and BASK 32-64 into Japanese. What has not been attended to so far is that TS BP 4-15 are meant for defending Dignāga's thesis noted above convincingly. The aim of this paper is to show how Śāntarakșita rebuts the counter-argument made by Śubhagupta.

1. Let us begin by considering BASK $38-40$ :

gang ltar snang de de las min // rdzas med phyir zla gnyis bzhin zhes ${ }^{\mathrm{i})} / /$ smras pa'i sgrub pa gang yin pa // de la'ang gtan tshigs ma nges nyid //38 rdul phran gang dag phrad gyur cing // rigs mthun bya ba gcig byed pa // de dag 'dus pa zhes brjod na // de dag rdzas med ga la zhig //39 gcig gi sgras brjod de dag ni // de dag la ni gcig med do // sgra yi don ni rnam brtags te // dbang po'i sems la mi snang ngo //40

i) gang ... A $\mathrm{A}$ 2ab: gang ltar snang de de las min // rdzas su med phyir zla gnyis bzhin // "[Dignāga formulates the following argument in ĀP 2ab:]

[Thesis:] The cognition which has the appearance of an [aggregate of atoms] is not what arises from an [aggregate of atoms];

[Reason:] Because it does not have a primary existence [as its objective basis];

[Example:] Like [the cognition which has the appearance of] the second moon.

[Answer:] In this argument of the vādin too, the logical reason ['not having a primary existence as its objective basis'] is inconclusive. (38) If one calls those atoms 'an aggregate,' which are of the same class and, after accumulating, produce a single effect, how can they be unreal? (39) Even if they are referred to by the word 'one,' they do not have the property of being one. The referent of a word is something conceptually constructed, and hence [an aggregate of atoms as a single entity] does not appear to sensory cognition. (40)"

It is important to note BASK 39-40. According to Śubhagupta, from the given logical rea- 
son it also must follow that the cognition which has the appearance of an aggregate of atoms arises from an aggregate of atoms. In his view, atoms have a single effect when accumulated. That is, after atoms combine into a perceptible mass form, they produce a single sensory cognition. When atoms accumulate, it is metaphorically said that a single aggregate of the atoms occurs. But in reality there are only individual atoms. Thus the cognition which has the appearance of an aggregate of atoms is nothing more than the one which has the appearance of individual atoms, thus it follows that cognition does not have a primary existence as its objective basis. From Subhagupta's viewpoint, the expression 'an aggregate of atoms' refers to individual atoms and an aggregate of individual atoms as a single entity is something mentally constructed.

The points Śubhagupta makes here are clear: (1) Atoms forming an aggregate is considered as an objective basis for sensory cognition; (2) such atoms are conceptually cognized as a single aggregate, which is unreal. It is to be noted in passing that Kamalaśila cites BASK 44 to show Śubhaguputa's view in his Tattvasangrahapañjikā (TSP) as follows:

athāpi syāt-samuditā evotpadyante vinaśyanti ceti siddhāntān naikaikaparamāṇupratibhāsa iti ${ }^{\mathrm{i})}$, yathoktam bhadantaśubhaguptena-

pratyekam na cānūnām svātantryenāsti sambhavah $/$

ato 'pi paramānūnām ekaikāpratibhāsanam //ii) $\operatorname{TSP}_{\mathrm{B}} 672,12$ on TS BP $6\left(\operatorname{TS}_{\mathrm{B}} 1969\right)$

i) samuditā ... cf. BASK 43. ii) pratyekam ... BASK 44 (HATTORI 1960: 10 list 3).

"One might have the following idea: According to the established view that only aggregates of atoms arise and perish, it is proper to say that they do not appear individually, as is stated by the Venerable Śubhagupta:

There is no arising of atoms individually on their own. And hence they do not appear individually."

2. Point (1) is argued by Śāntarakșita in TS BP 4-7.

2.1. To begin with, Sāntarakșita assumes the case where atoms which Śubhagupta considers to be perceptible are isolated from, not in contact with, one another.

na tāvat paramānūnām ākārah prativedyate I

niramśānekamūrtānām pratyayāprativedanāt $\left.{ }^{\mathrm{i}}\right)$ // TS BP $4\left(\mathrm{TS}_{\mathrm{B}} 1967\right)$

vyapetabhāgabhedā hi bhāseran paramānavah /

nānyathādhyakșatā teșām ātmākārāsamarpanāt // TS BP 5 (TS 1968$)$

i) ${ }^{\circ} m \bar{u} r t \bar{a} n \bar{a} m$ pratyay $\bar{a}^{\circ} \mathrm{J} \mathrm{G}$, lus can shes la $\mathrm{T}$; ${ }^{\circ}$ mūrtābhapratyaya $\bar{a}^{\circ} \mathrm{Pa} \mathrm{B}$.

"First of all, one does not experience a form of atoms because one does not experience an awareness of several impartite corporeal things, for atoms would appear as not having distinct parts separate from each other. Otherwise, they would not be visible because they do not yield an image of themselves." 
Sanntarakșita points out that atoms, each of which has the status of being impartite, cannot appear to sensory cognition and hence imperceptible. If atoms, each of which is indivisible, appeared to sensory cognition, then it would follow that they are perceptible; but, atoms do not project the images of themselves onto the sensory cognition. ${ }^{1)}$

2.2. Next Śantarakșita assumes the case where atoms are in association with one another. Obviously, this case is the one where the atoms accumulate.

Subhagupta might raise the following objection:

sāhityenāpi jātās te svarūpenaiva bhāsinah /

tyajanty anamśarūpatvam na cet tāsu daśāsv amī // TS BP $6\left(\mathrm{TS}_{\mathrm{B}} 1969\right)$

"[Objection:] The [atoms], arising even in association [with one another], will appear only with their own form. In the state of being associated with one another, they do not abandon their form of partlessness."

The point Śubhagupta makes is as follows. Atoms are associated with one another, however, even in such a situation they do not lose their form of partlessness. Such atoms appear to sensory cognition.

Śāntarakșita answers this objection as follows:

labdhāpacayaparyantam rūpam teșām samasti cet /

katham nāma na te 'mūrtāi ${ }^{\mathrm{i}}$ bhaveyur vedanādivat // TS BP $7\left(\mathrm{TS}_{\mathrm{B}} 1970\right)$

i) 'mūrtā G, lus med T; mūrtā B.

"[Answer:] If they have the form of being at the limit of diminution, then how could they not be incorporeal, like sensation and so forth?"

Here Sāntarakșita brings up the assumption that a corporeal thing is divisible. Thus, whatever is not divisible is not a corporeal thing. Accordingly, it follows that an atom, which is beyond further division, is an incorporeal thing. Of course, this conclusion is not acceptable to Śubhagupta.

3. Point (2) is argued by Sāntarakșita in TS BP 8-9. In order to justify point (2), Śubhagupta says the following:

\section{tulyāparakṣanotpādād yathā nityatvavibhramah /}

avicchinnasajātīyagrahe cet sthülavibhramah ${ }^{\mathrm{i})} / /^{\mathrm{ii})} \mathrm{TS} \mathrm{BP} 8\left(\mathrm{TS}_{\mathrm{B}} 1971\right)$

i) sthūla ${ }^{\circ} \mathrm{J}$ Pa G B, rags pa em. rigs pa $\mathrm{T}$; sngon po nyid du BASK. ii) tulya $\bar{a}^{\circ}$. . BASK 35

(HATTORI 1960: 10 list 2).

"[Objection:] Just as [a given entity] is erroneously cognized as being eternal because there arise similar succeeding moments, so atoms which do not occupy the different regions of space separated from one another and which are of the same class are erroneously cognized as a gross entity when 
they are grasped simultaneously."

According to Subhagupta, in the situation where atoms accumulate and bring about a single sensory cognition, they do not occupy the different regions of space that separate them from one another and are treated as being of the same class. Atoms in such a situation are erroneously cognized as a gross entity, as an aggregate of atoms.

Śāntarakșita rejects this view:

svavyāpārabalenaiva pratyakșam janayed yadi I

na parāmarśavijñānam katham te 'dhyakșagocarāh // TS BP $9\left(\mathrm{TS}_{\mathrm{B}} 1972\right)$

"[Answer:] If a perceptual cognition did not produce the reflective cognition [of certain things] by the force of its own function, then how could they be the object of perceptual cognition?"

Suppose that there are different things within the scope of perceptual cognition. According to Sāntarakșita, only what can be grasped reflectively as in 'This is such and such' deserves to be the object of perceptual cognition. If atoms are the object of sensory cognition, there must arise the reflective awareness that 'These are atoms.' But experience tells us that such reflective awareness does not occur. It goes without saying that reflective awareness, which is perceptual judgment, is of erroneous nature.

4. Even Śubhagupta has to accept that the color yellow appears to sensory cognition. Thus, how does one logically establish that the cognition with the appearance of the color yellow arises from atoms? This question is discussed by Śāntarakșita in TS BP 10-15.

4.1. Sāntarakṣita says the following:

kṣaṇikā iti bhāvāśs ca niścìyante pramānatah ${ }^{\mathrm{i})}$ /

anavas tv iti gamyante katham pittasitādayah //TS BP $10\left(\mathrm{TS}_{\mathrm{B}} 1973\right)$

i) rjes su dpag pas $\mathrm{T}$ for pramānatah.

"In addition, things are determined to be momentary through valid means of cognition. But how could the colors yellow, white, and so on be understood to be atoms [through valid means of cognition]?"

In Śāntarakșita's view, there is no valid means of cognition to prove the thesis that the color yellow which is experienced consists of atoms.

4.2. Subhagupta presents the following argument to establish the above-stated thesis. sūkșmapracayarūpam hi sthülatvād ādyacākșușam ${ }^{\mathrm{i})}$ / parvatādivad atrāpi samastv eșānumeti cet $/ /^{\mathrm{ii})} \mathrm{TS} \mathrm{BP} 11\left(\mathrm{TS}_{\mathrm{B}} 1974\right)$

i) $\bar{a} d y a^{\circ} \mathrm{J} \mathrm{Pa} \mathrm{G} ; b \bar{a} h y a^{\circ} \mathrm{B}$, phyi rol T. ii) sūkșma ... n.e. BASK.

"Concerning this [thesis in question] too, the following argument must be given:

[Thesis:] The first visible thing consists of an accumulation of subtle things; 
[Reason:] Because it is gross;

[Example:] Like a thing such as a mountain."

4.3. Sāntarakșita points out fallacies in the logical reason 'being gross' as used in the above argument.

sthūlatvam vastudharmo hi siddham dharmidvaye 'pi na /

na hy asty avayavì sthūlo nānavaś ca tathāvidhāh // TS BP $12\left(\mathrm{TS}_{\mathrm{B}} 1975\right)$

"The property of being gross, inasmuch as it is the property of a real entity, is not established in both the property-bearers [i.e., the locus of the property to be proved and a similar example].

It is because that there is neither gross whole; nor are atoms gross in the same way."

For Śubhagupta, what can be defined as gross is twofold: a whole which is made up of parts and atoms. But in his view, a whole cannot be accepted as a reality; nor can atoms have the property of being gross even if they are metaphorically called 'gross.' If the first visible thing and a mountain were regarded as being a whole or as consisting of atoms, it would follow that the property of being gross, that of a real entity, could not be attributed to them.

4.4. Another interpretation of 'being gross' is provided by Śāntaraksita. atha deśavitānena sthitarūpam tathoditam / tathāpi bhrāntavijñānabhāsirūpena samśayah̆ // TS BP $13\left(\mathrm{TS}_{\mathrm{B}} 1976\right)$

“[Objection:] The color which has spatial extension is spoken of as 'gross.'

[Answer:] Even so, [the logical reason is] dubious since such color appears to erroneous cognition [like dreaming cognition]."

What is spoken of as 'gross' is something that has spatial extension. The color which has spatial extension appears to erroneous cognition, similar to cognitive experienced in dreams. According to Śāntarakșita, however, the color which appears to dreaming cognition has no external counterpart which Śubhagupta holds to be an accumulation of atoms. 4.5. According to Kamalaśîla, Śubhagupta might modify the above-noted argument as follows: ${ }^{2)}$

[Thesis:] The first visible thing consists of an accumulation of subtle things;

[Reason:] Because it is not erroneously cognized and is gross;

[Example:] Like a thing such as a mountain.

Śāntarakșita points out fallacies in the logical reason "not being erroneously cognized and being gross' used in this argument.

vaitathyāt sa tathā no ced vyatireke 'prasādhite /

tasmād atiśayah ko 'sya kāryasamvādanam yadi // TS BP $14\left(\mathrm{TS}_{\mathrm{B}} 1977\right)$ 
kāryāvabhāsivijūānasamvāde 'pi nanūcyate ${ }^{\mathrm{i})} /$

sāmarthyaniyamād dhetoh sa ca sambhāvyate 'nyathā // TS BP $15\left(\mathrm{TS}_{\mathrm{B}} 1978\right)$

i) nanūcyate J Pa G, brjod pa yin $\mathrm{T}$; na tūcyate $\mathrm{B}$.

"If the [reason] is not thus [i.e., inconclusive] because [the Vijñānavādin's assumption that the cognition is erroneous] is false (vaitathya $\bar{a}$ ) inasmuch as the difference [of correct cognition from false cognition] is not established, what superiority does it have over [false cognition] when [correct cognition] is said to have the reliability with regard to its effect?

Even in the case where [correct cognition] is said to have the reliability with regard to the cognition in which the effect appears, isn't it indeed said that [the logical reason remains dubious]?

Furthermore, since the cause [of producing such cognition, i.e., its preceding homogenous cause] is restricted to a specific capacity, it is possible to explain the [reliability as described above] in a different manner [i.e., without assuming an external object]."

According to Sāntarakșita, the distinction is to be made between erroneous and correctin the sense of having an external object-cognitions. Subhagupta may say that the former does not have the reliability with regard to its effect, while the latter has the reliability. According to Śāntarakșita, however, erroneous cognition such as dreaming cognition leads to the effect: nocturnal emission during sleep accompanied by an erotic dream. The process of leading to an effect is similar in both cases of cognition. In the view of Śāntarakșita, whether or not a cognition leads to a reliable effect depends on whether or not its preceding homogenous cause has the capacity to produce such cognition; irrespective of the existence or non-existence of an external object.

We notice that in TS BP 15 Śāntarakșita brings out the point made by Dignāga in ĀP 6 that an objective basis for cognition can be sought in the cognition itself without assuming the external world. ${ }^{3)}$

5. We have seen how Śāntarakșita rebuts the counter-argument by Śubhagupta to establish that an aggregate of atoms should be regarded as an objective basis for cognition. Subhagupta holds the view that atoms, when accumulated, bring about sensory cognition and that they are erroneously cognized as a single entity, like the color yellow. Śāntarakṣita disputes this view in three ways by considering 1) how atoms are; 2) what erroneous cognition arises immediately after the perceptual cognition of atoms takes place; 3 ) and whether inference can prove that what is directly experienced has an external counterpart which consists of atoms. Clearly, Śāntarakșita adopts a strategy that leads us to the conclusion that in accordance with Dignāga a cognitive event can be accounted for without assuming the external world. 
* I am deeply grateful to Prof. Brendan Gillon and Prof. Helmut Krasser whose suggestions were of inestimable value for this paper.

〈Notes〉 1) See ĀP 1: dbang po rnam par rig pa'i rgyu // phra rab rdul dag yin mod kyi // der mi snang phyir de'i yul ni // rdul phran ma yin dbang po bzhin // 2 2) See $\operatorname{TSP}_{\mathrm{B}}$ 674, 18: athābhrāntatve satîti viśeșanam upādiyate/ 3 ) AP 6: nang gi shes bya'i ngo bo ni // phyi rol ltar snang gang yin de // don yin rnam shes ngo bo'i phyir // de rkyen nyid kyang yin phyir ro //

〈Literature and abbreviations〉 ĀP Ālambanaparikșā: E. Frauwallner, "Dignāgas Ālambanaparīkșā.” WZKM 37 (1930): 174-94. BASK Bāhyārthasiddhikārikā: Eshō Mikogami 神子上恵生. “Śubhagupta no Bāhyārthasiddhikārikā シュバグプタの Bāhyārthasiddhikārikā.” Ryūkoku Daigaku Ronshū 龍谷大学論集 429 (1986): 2-44. BP TS/P, ch. 23 Bahirarthaparīkṣā. HATTORI, M. 1960. "Bāhyārthasiddhikārikā of Śubhagupta." Indo-gaku Bukkyō-gaku Kenkyū 印度学仏教学研究 8-1: 9-14. MATILAL, B. 1981. "Error and Truth—Classical Indian Theories." Philosophy East and West 31-2: 214-24. MıkoGaMI, Esho 神子上恵生. 1983. "Śubhagupta no gokumi-ron no yōgo シュバグプタの極微論

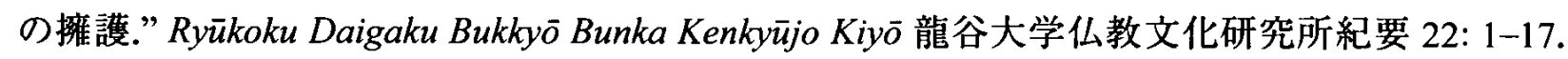
TS/P $\mathbf{P}_{\mathbf{T}}$, T Tibetan trans. ( $\left.\mathrm{D}=\mathrm{P}\right)$. $\mathbf{T S}_{\mathbf{B}}, \mathbf{B}$ Tattvasañgraha: Tattvasagningraha of Ācārya Shāntarakșita with the Commentary 'Pañjikā' of Shri Kamalashīla. 2 vols. Ed. S. Śāstri. Vāraṇasī: Bauddha Bhārati

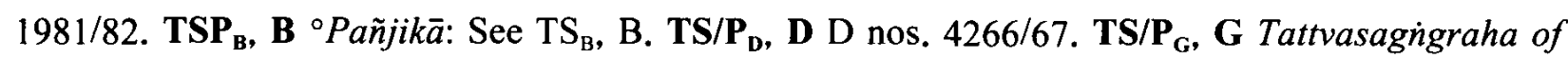
Śāntarakșita with the Commentary of Kamalaśila. 2 vols. Ed. E. Kṛṣnamācārya. Baroda: Oriental In-

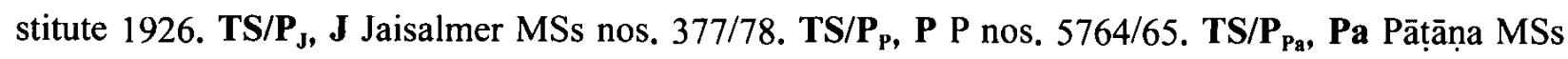
nos. 6679/80.

(This work was supported in part by a Grant-in-Aid for JSPS Fellows.)

〈Key words〉 Dignāga, Śubhagupta, Śāntarakșita, Ālambanaparīkșā, Bāhyārthasiddhikārikā, Tattvasañgraha, Bahirarthaparīkṣā, paramānu

(JSPS Research Fellow) 